Article

\title{
Timing of Secondary Hydrothermal Alteration of the Luobusa Chromitites Constrained by Ar/Ar Dating of Chrome Chlorites
}

\author{
Wei Guo ${ }^{1,2,3}$, Huaiyu $\mathrm{He}^{1,2,3, *}$, Youjuan $\mathrm{Li}^{4}$, Xiujuan Bai ${ }^{5}$, Fei Su ${ }^{1,2}$, Yan Liu ${ }^{6}$ and \\ Rixiang Zhu ${ }^{1,2}$ \\ 1 State Key Laboratory of Lithospheric Evolution, Institute of Geology and Geophysics, Chinese Academy \\ of Sciences, Beijing 100029, China; bruceguowei@foxmail.com (W.G.); sufei@mail.iggcas.ac.cn (F.S.); \\ rxzhu@mail.iggcas.ac.cn (R.Z.) \\ 2 Institutes of Earth Science, Chinese Academy of Sciences, Beijing 100029, China \\ 3 College of Earth and Planetary Sciences, University of Chinese Academy of Sciences, Beijing 100049, China \\ 4 State Key Laboratory of Earthquake Dynamics, Institute of Geology, China Earthquake Administration, \\ Beijing 100029, China; youjuanli6@163.com \\ 5 MOE Key Laboratory of Tectonics and Petroleum Resources, China University of Geosciences, \\ Wuhan 430074, China; xiuj.bai@cug.edu.cn \\ 6 State Key Laboratory of Continental Tectonic and Dynamics, Institute of Geology, Chinese Academy of \\ Geological Sciences, Beijing 100037, China; ly@cags.ac.cn \\ * Correspondence: huaiyuhe@mail.iggcas.ac.cn
}

Received: 8 May 2018; Accepted: 23 May 2018; Published: 29 May 2018

\begin{abstract}
Chrome chlorites are usually found as secondary phases formed by hydrothermal alteration of chromite deposits and associated mafic/ultramafic rocks. Here, we report the ${ }^{40} \mathrm{Ar} /{ }^{39} \mathrm{Ar}$ age of chrome chlorites separated from the Luobusa massive chromitites which have undergone secondary alteration by $\mathrm{CO}_{2}$-rich hydrothermal fluids. The dating results reveal that the intermediate heating steps (from 4 to 10) of sample L7 generate an age plateau of $29.88 \pm 0.42 \mathrm{Ma}$ (MSWD $=0.12$, plateau ${ }^{39} \mathrm{Ar}=74.6 \%$ ), and the plateau data points define a concordant inverse isochron age of $30.15 \pm 1.05 \mathrm{Ma}\left(\mathrm{MSWD}=0.08\right.$, initial $\left.{ }^{40} \mathrm{Ar} /{ }^{36} \mathrm{Ar}=295.8 \pm 9.7\right)$. The Ar release pattern shows no evidence of later degassing or inherited radiogenic component indicated by an atmospheric intercept, thus representing the age of the hydrothermal activity. Based on the agreement of this hydrothermal age with the $\sim 30 \mathrm{Ma}$ adakitic plutons exposed in nearby regions (the Zedong area, tens of kilometers west Luobusa) and the extensive late Oligocene plutonism distributed along the southeastern Gangdese magmatic belt, it is suggested that the hydrothermal fluids are likely related to the $\sim 30$ Ma magmatism. The hydrothermal fluid circulation could be launched either by remote plutons (such as the Sangri granodiorite, the nearest $~ 30$ Ma pluton west Luobusa) or by a similar coeval pluton in the local Luobusa area (inferred, not found or reported so far). Our results provide important clues for when the listwanites in Luobusa were formed.
\end{abstract}

Keywords: Ar/Ar dating; chrome chlorite; Luobusa chromitites; hydrothermal alteration

\section{Introduction}

Over the past two decades, podiform chromitites in Luobusa, Tibet, and the host peridotites were extensively studied to understand their petrogenesis and related tectonic evolutions. These studies include: major and trace elemental and/or isotopic compositions of different textural chromitites and their host peridotites (e.g., [1-8]), and unusual ultrahigh-pressure (UHP), highly reduced and crustally derived minerals found either in situ or as separates in the chromitites and peridotites (e.g., [9-21]). 
Most of the above studies focus on primary features of the chromitites and try to clarify the mechanisms and processes involved in their formation. Fewer attention was drawn to secondary alteration or deformation of the chromitites since they were formed and finally emplaced.

Despite the fact that chromites within chromitites and peridotites are in general better preserved than silicates as they are more resistant to fluid-related process, textural and chemical alteration of chromites may occur during retrograde/prograde metamorphic events and depend on the degrees of metamorphism (e.g., [22-24]). Moreover, mafic and ultramafic peridotitic rocks (fresh or serpentinized) are readily altered by silica- and $\mathrm{CO}_{2}$-rich hydrothermal fluids to form listwanites after their emplacement in orogenic belts [25-28]. The alteration process is potentially associated with economic mineralization, as represented by the formation of gold deposits [27,29-31]. Listwanites in Luobusa were first reported by Robinson et al. [27], who reported detailed mineralogy, petrography, and geochemistry of the listwanites. As a further part of this work, Zhang et al. [28] recently refined the mineral-transformation processes corresponding to different degrees of alteration intensity during listwanite formation. They also noted a preliminary enrichment of gold and mercury in the listwanites. Nevertheless, the fluid source and origin of the Luobusa listwanites are poorly constrained and thus much debated. Determination of the hydrothermal age is one key piece of information to resolve this problem especially when a spatial correlation between the hydrothermal alteration and any known intrusive activity is absent (e.g., [27]). Chrome chlorites formed during this hydrothermal event are chosen to perform the age determination by the Ar/Ar method, as other hydrothermal minerals like Cr-bearing mica which is more appropriate for Ar/Ar dating have not been identified so far.

The term "chrome chlorite" is used for the violet or pink colored chlorite containing chromium to differentiate it from the green Fe-Mg chlorite [32], although the nomenclature of chrome chlorite is complicated based on its $\mathrm{Cr}_{2} \mathrm{O}_{3}$ contents and the position of chromium substituting for $\mathrm{Al}$ in the chlorite structure (e.g., [33]). They are usually formed as secondary phases during hydrothermal alteration of podiform chromitites and associated mafic/ultramafic rocks (e.g., [27,32,34,35]). Despite the fact that $\mathrm{Ar} / \mathrm{Ar}$ dating of chlorite is difficult and even impossible in many cases, successful application lies in careful selection and preparation of the chlorite samples with elevated K contents [36]. The new generation of noble gas mass spectrometer ARGUS VI, with high sensitivity and multi-collector, enables dating of very young (ca. ka level) samples or samples with low/ultra-low potassium contents (e.g., $[37,38])$. In this study, the pinkish hydrothermal chrome chlorites within the massive chromitites in Luobusa are first reported and dated by the Ar/Ar technique to provide age constraints for the secondary hydrothermal event.

\section{Geological Background}

The Himalaya-Tibetan orogenic system, one of the most exceptional geologic features on the surface of the Earth, is composed of several blocks, or terranes. From north to south, the principal terranes are Songpan-Ganzi, Qiangtang, Lhasa, and Himalaya, which are bound by the Jinsha, Bangong-Nujiang, and Yarlung-Zangbo suture zones [39,40] (Figure 1a). The Yarlung-Zangbo suture zone (YZSZ), youngest among the sutures listed above, extends for $\sim 2000 \mathrm{~km}$ in a nearly E-W direction and marks where the Tethys ocean was consumed and the ultimate collision between India and Asia occurred [41]. The suture is composed of a nearly continuous subduction-related complex and ophiolite belt which represents the remnants of Tethys oceanic lithosphere. While rocks or units with different affinities within the YZSZ are tectonically disrupted everywhere, relatively complete ophiolite sequences can be found at the Zedong-Luobusa area southeast of Lhasa [41] (Figure 1b). 


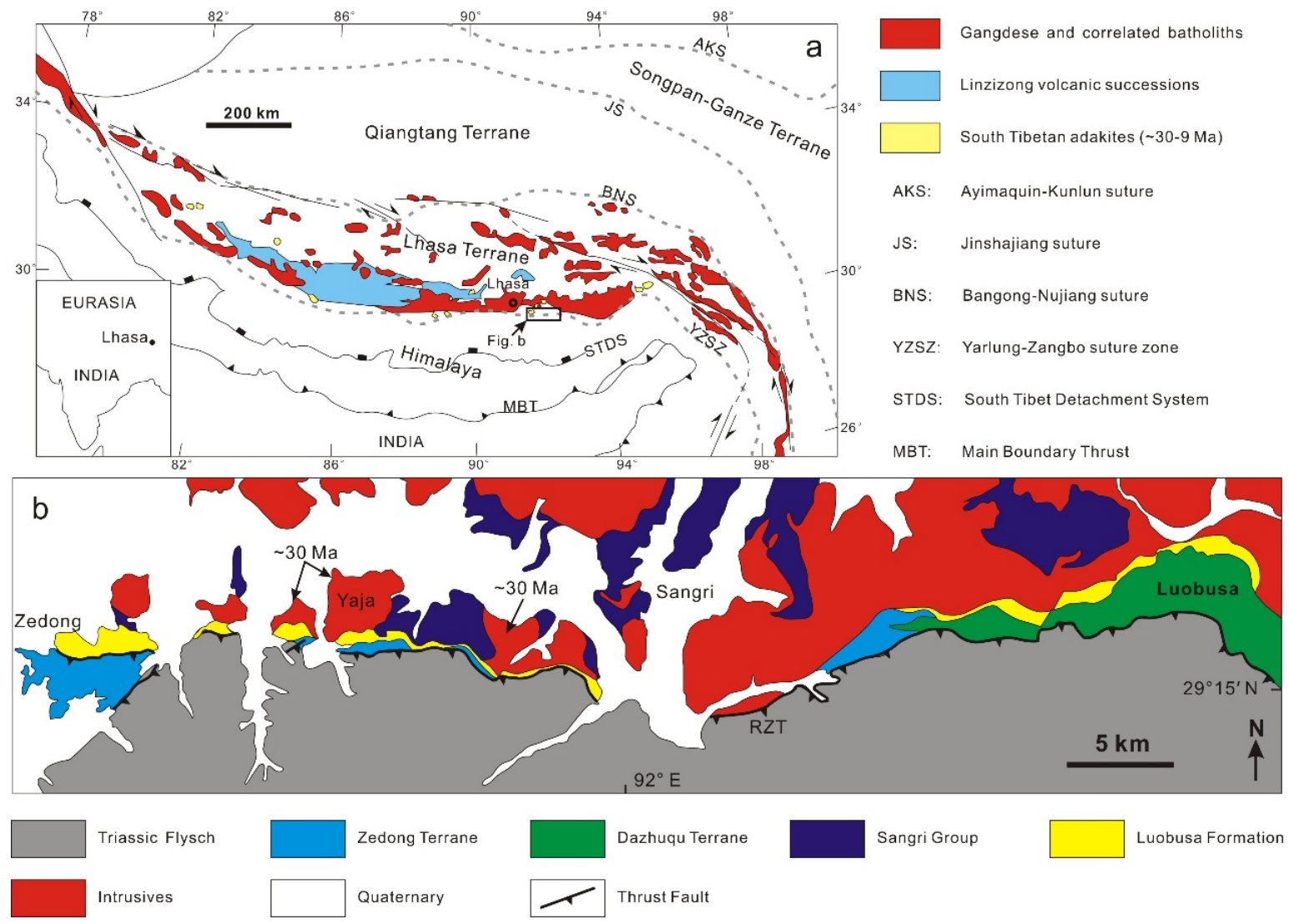

Figure 1. (a) Simplified tectonic framework of the Himalayan-Tibetan orogen (modified from Hou et al. [42]), and the distribution of magmatism on the Lhasa terrane (modified from Chung et al. [43]). (b) Geological map of the study area (Zedong-Luobusa), modified from Aitchison et al. [44]. The $\sim 30$ Ma intrusives are marked on the map based on references $[43,45-50]$. RZT $=$ Renbu-Zedong thrust.

The Luobusa ophiolite, as a tectonic slice, has been thrust northwards over multiple Tertiary molasse units of the Luobusa Formation or onto the Gangdese batholith and is itself tectonically overlain by Triassic flysch deposits to the south [7,51]. Rocks of the ophiolite incorporate a tectonic mélange zone, a transition zone, and a mantle sequence from north to south. The mélange zone contains disrupted lenses of pillow lava and cumulative rocks including wehrlite, pyroxenite, and layered gabbros. The transition zone is massive dunite, several to hundreds of meters in thickness. The mantle sequence consists of clinopyroxene-bearing harzburgites (lherzolites) and harzburgites which contain dunite lenses and abundant pods of chromitites [6,7,41].

Podiform chromitites in Luobusa comprise the largest historical chromite deposit in China. They contain $>5$ million tons of ore-grade material and have been mined for several decades [52]. The chromitites display several different ore-structure types, in which nodular, disseminated, and massive are the most common. Each chromitite type is often transected by another, indicating a multi-stage magmatic history $[7,18]$. The chromitites were initially thought to have bearing on the formation and evolution of the ophiolite. The Luobusa ophiolite originated at a mid-ocean ridge spreading center at $177 \pm 31 \mathrm{Ma}$ and was later modified by supra-subduction zone (SSZ) magmatism at $120 \pm 10 \mathrm{Ma}$ involving an intra-oceanic subduction system [5-7,41,53,54]. However, the presence of ultrahigh-pressure (UHP) and highly reduced minerals such as diamond, coesite, and native elements, initially found in the chromitites but more recently also in their host peridotites, requires additional processes or models to outline the genesis of the chromitites (e.g., $[4,10,11,13,17-20,55-57])$. 
The reported listwanites in Luobusa are distributed along the southern boundary fault of the ophiolite [27]. Most occur in the eastern region of the ophiolite, but a few small outcrops are also present in the southwest [28]. They are light-to orange-brown, fractured and altered peridotites, with a sharp contact with Triassic flysch to the south but gradational with the host peridotites to the north. According to the different intensities of alteration, three zones are identified from the southern boundary to the northern host peridotites [28]. Hydrothermal veins, mostly 1-3 mm wide, are common in the listwanites and occasionally intrude the massive chromitites [27]. The listwanites consist essentially of talc and magnesite with lesser amounts of quartz, although CaO-rich minerals like dolomite may occur in fewer samples. Most of the listwanites are indistinguishable geochemically from the unserpentinized protoliths except for having a notably higher loss on ignition [27].

Igneous activity along the Gangdese magmatic belt took place from the Late Triassic to the Miocene in four discrete stages at 205-152, 109-80, 65-41, and 33-13 Ma [58]. Mesozoic granites and associated volcanic rocks were formed by the northward Neotethyan subduction [58]. The most prominent magmatic episode occurred in the Paleocene-Eocene (65-41 Ma). Formation of the Linzizong volcanic successions and their coeval granitoids are attributed to a syn-collisional setting created in response to the collision between Asia and India [59,60], or by rollback of the subducting oceanic slab and subsequent slab break-off [58,61-64]. Post-collisional magmatism is marked by collision-type adakites and contemporaneous potassic-ultrapotassic volcanic rocks with ages from $\sim 26$ to $\sim 10 \mathrm{Ma}$ [42,61,65-68]. These rocks are generally interpreted to be linked to a complex magmatic and tectonic evolution of the mafic lower crust, lithospheric mantle, and subducting slab beneath the Lhasa terrane, involving mechanisms such as convective removal of the lower lithosphere or slab breakoff [67], and melting of thickened lower crust due to lithospheric root foundering and plateau collapse $[42,43,58,61,66]$. The period of $\sim 40-25 \mathrm{Ma}$ [59] or to $30 \mathrm{Ma}$ [43] is thought to be magmatically quiescent, accompanied by crustal shortening or lithosphere thickening [43,59].

\section{Samples and Analytical Methods}

A simple description of the suite of chromitite samples, including the ones used in this study, was presented in Guo et al. [1]. Two massive chromitite samples (L6 and L7), more heavily altered by hydrothermal fluids, are chosen for this study, as more secondary minerals may be obtained for dating. On specimen scale, the hydrothermal alteration usually forms planar alteration zones and intrusive veins with abundant patches of chrome chlorites and carbonates (Figure 2a,b). The chrome chlorites are from colorless to greenish (rare) and to pinkish (dominated), probably reflecting the variations of $\mathrm{Cr}$ contents in them. They are present as scales and flakes. Combined with the pinkish color they were once thought to be lepidolites before careful observation under microscope and composition analysis. Thin section study reveals that the carbonate minerals occur in intrusive veins with rhombohedral crystals of calcite, mostly showing growth zoning, surrounded by dolomites (Figure 2c,d). Chrome chlorites occur as veins or inclusions in the massive chromite matrix which is highly fractured by hydrothermal fluids (Figure 2e,f).

Quantitative chemical composition analyses were performed on selected minerals using a JXA-8100 electron microprobe (produced by the JEOL Company, Tokyo, Japan) at Institute of Geology and Geophysics, Chinese Academy of Sciences, Beijing (IGGCAS). The microprobe was set to operate at a voltage of $15 \mathrm{kV}$ and a beam current of $10 \mathrm{nA}$ with a focus beam diameter of $5 \mu \mathrm{m}$. Results were corrected with the conventional ZAF procedure. 


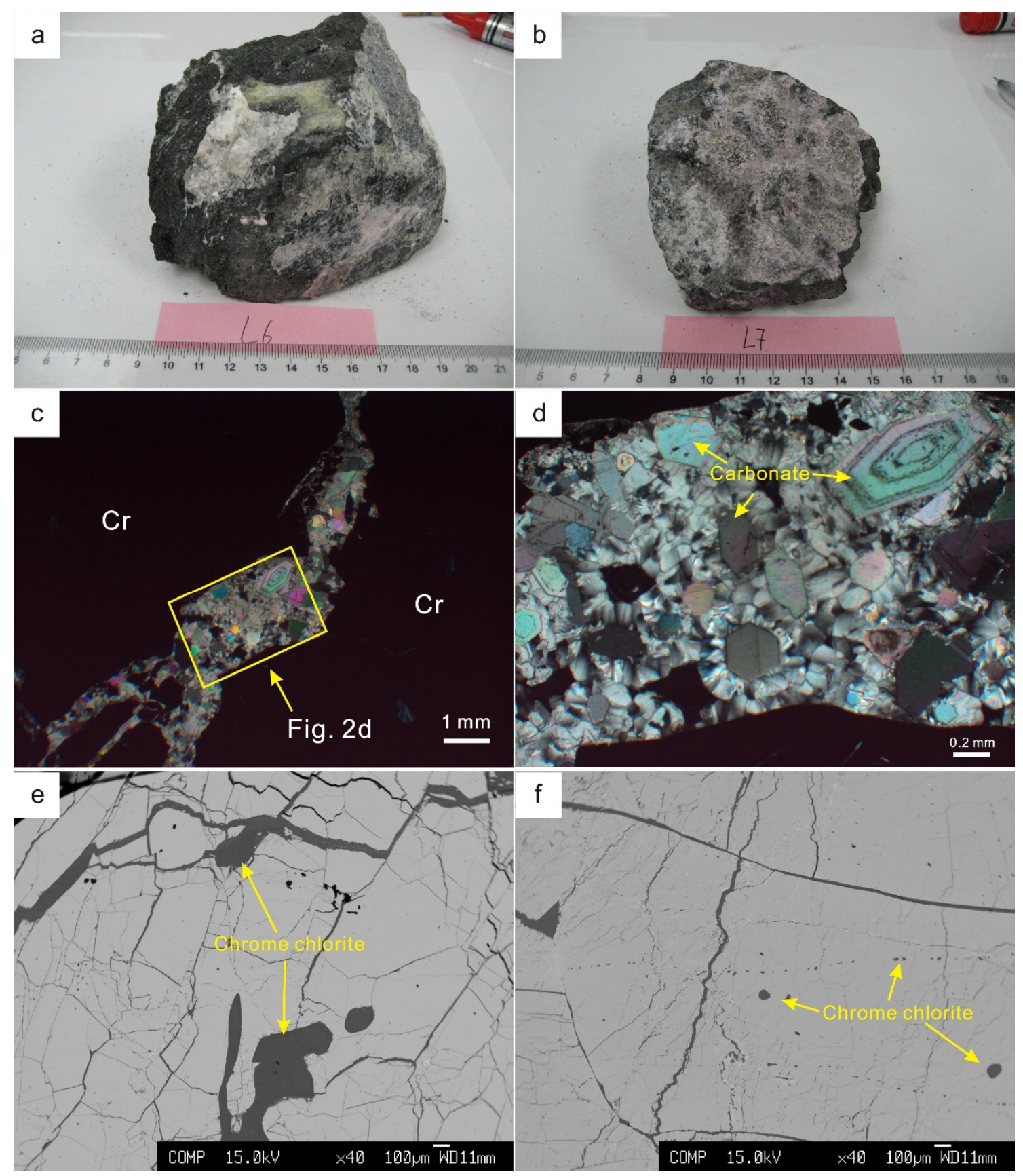

Figure 2. (a,b) Hand specimen of massive chromitites showing late alteration by $\mathrm{CO}_{2}$-rich hydrothermal fluids and occurrence of secondary minerals, chrome chlorites and carbonates. (c,d) Thin section observation of a carbonate vein from L6. The rhombohedral crystals with zonal structure are calcites, surrounded by dolomites. (e,f) BSE images showing the occurrence of chrome chlorites in thin sections. $\mathrm{Cr}=$ Chromite.

Single crystal X-ray diffraction (XRD) analysis (Figure 3a,b) was performed on chrome chlorite using the SMART APEX II (a legacy product of the Bruker Corporation, Billerica, MA, USA) at Institute of Microstructure and Properties of Advanced Materials, Beijing University of Technology. Data were processed using the SHELX programs which were developed by George M. Sheldrick in Germany. 

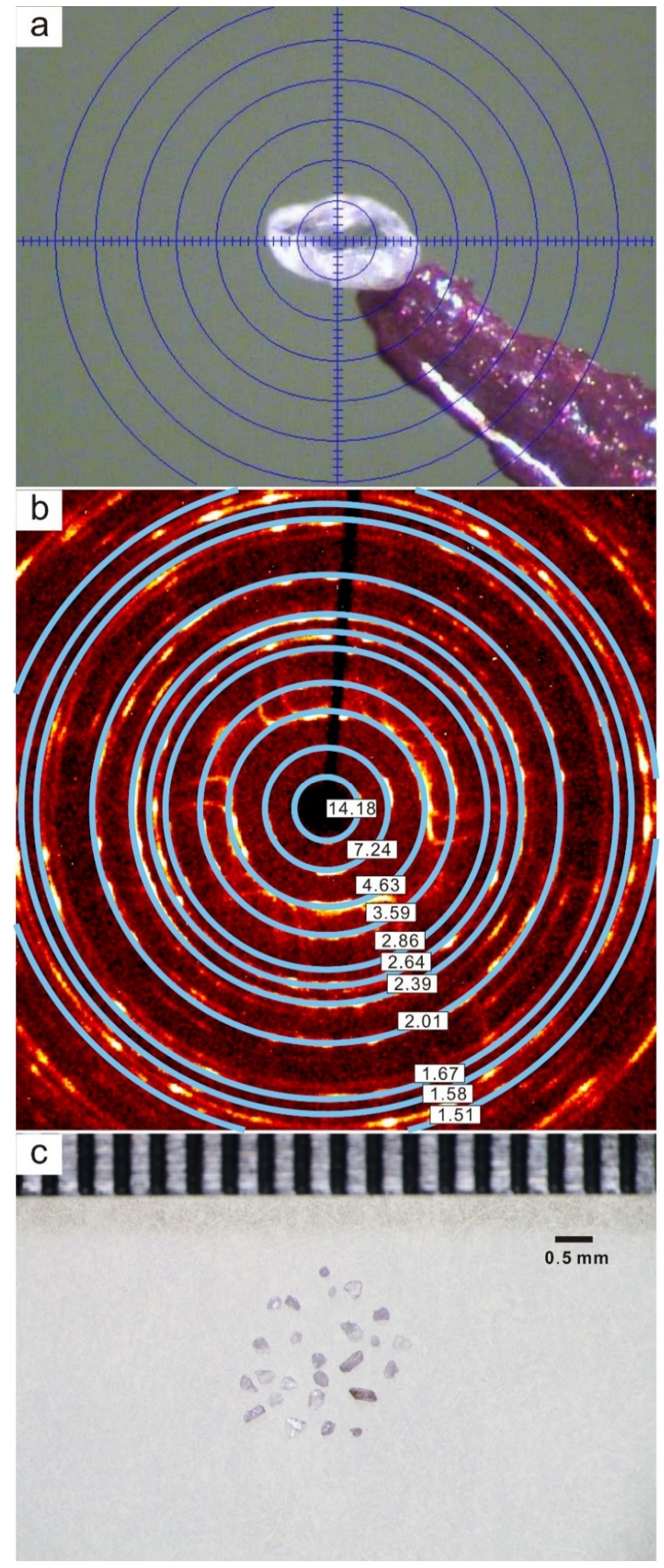

Figure 3. (a) Single crystal of chrome chlorite used for X-ray diffraction experiment. (b) Representative d-spacings of the chrome chlorite in the single crystal XRD experiment. (c) The occurrence of chrome chlorite separates for Ar/Ar dating experiment.

Mineral separates of pure chrome chlorite for ${ }^{40} \mathrm{Ar} /{ }^{39} \mathrm{Ar}$ analyses were carefully picked out by hand under a binocular microscope after crushing the massive chromitites into appropriate pieces. 
The separates (Figure 3c), 200-500 $\mu \mathrm{m}$ in size, were first washed in an ultrasonic bath with dilute $\mathrm{HNO}_{3}(<5 \%$ in volume) for $20 \mathrm{~min}$, then followed by washes with deionized water and acetone to remove possible altered products. Two aliquots $(15 \mathrm{mg})$ of each sample were wrapped individually in aluminum foil and stacked together with interspaced aliquots of the Fish Canyon sanidine (FCs) standard (28.201 $\pm 0.046 \mathrm{Ma}$ [69]) in a vacuum sealed quartz tube (5 $\mathrm{mm}$ in diameter). The samples and FCs standard, coated with $0.5 \mathrm{~mm}$ thick $\mathrm{Cd}$ foil on the tube for shielding thermal neutrons, were irradiated at position B4 of the 49-2 Nuclear Reactor, Beijing (China) for $24 \mathrm{~h}$. The J-value for each sample was calculated based on the monitor data and relative position of the sample to monitor in the tube (4 FCs flux monitors were used within a distance of $17 \mathrm{~mm}$ ). The uncertainty of $0.36 \%(2 \sigma)$ for the $J$-value was propagated into the age calculations.

Subsequent laser stepwise-heating experiments were performed on an ARGUS VI mass spectrometer (produced by the Thermo Scientific, Waltham, MA, USA) at the ${ }^{40} \mathrm{Ar} /{ }^{39} \mathrm{Ar}$ dating laboratory in China University of Geosciences (Wuhan). Around $12 \mathrm{mg}$ of each aliquot was loaded into the laser chamber and heated for 12 total steps with increasing heating power of the laser. Gases extracted at each step were first passed through a cryotrap $\left(-80\right.$ to $\left.-120^{\circ} \mathrm{C}\right)$ to adsorb moisture, then further purified by two SAES NP $10 \mathrm{Zr}$-Al getters (one at $\sim 400{ }^{\circ} \mathrm{C}$ and the other at room temperature) [70]. Afterwards, pure noble gases were admitted into the mass spectrometer for argon isotope analyses. All of these procedures were run by automatic techniques detailed by Qiu et al. [71] and Bai et al. [37]. Raw data were processed and plotted using the ArArCALC (Version 2.4) software [72]. After irradiation, samples were kept in the laboratory for several months prior to argon measurements. Therefore, the interfering argon isotopes derived from irradiated $\mathrm{CaF}_{2}$ were not corrected (also because Ca contents of the samples are trace), however, for the irradiated $\mathrm{K}_{2} \mathrm{SO}_{4}$, the correction factor is: $\left({ }^{40} \mathrm{Ar} /{ }^{39} \mathrm{Ar}\right)_{\mathrm{K}}=3.3 \times 10^{-4}$ [73].

\section{Results}

\subsection{Mineral Chemistry}

Major element data of massive chromites of L6 and L7 were reported by Guo et al. [1]. The chromites have $100[\mathrm{Cr} /(\mathrm{Cr}+\mathrm{Al})]$ atomic ratios ranging between 75 and 79 , and $100\left[\mathrm{Mg} /\left(\mathrm{Mg}+\mathrm{Fe}^{2+}\right)\right]$ atomic ratios between 72 and $75 . \mathrm{Cr}_{2} \mathrm{O}_{3}$ ranges between 56 and $61 \mathrm{wt} \%$; $\mathrm{MgO}$ between 15 and $16 \mathrm{wt} \%$; $\mathrm{Al}_{2} \mathrm{O}_{3}$ between 10 and $14 \mathrm{wt} \%$; $\mathrm{FeO}$ (total iron) between 12 and $14 \mathrm{wt} \%$ (number of individual analysis point is 16). The chemical compositions of the chromites show that they are magmatic chromite grains $[1,8]$. Analytical profiles across chromites were not performed because there is no individual crystal showing compositional variations based on BSE scanning images. Nevertheless, in some cases, tiny scattered minerals, with higher reflectivity occurring along the contact between chrome chlorites (vein or inclusion) and chromites within the chromite's side, are probably ferritchromites (Figure 2e,f). They are too small to precisely determine their compositions.

The electron microprobe analysis (EMPA) data of the chrome chlorites are listed in Table 1. They are chrome chlorites marked by relatively high $\mathrm{Cr}_{2} \mathrm{O}_{3}(0.10-7.43 \mathrm{wt} \%), \mathrm{MgO}(33.84-35.52 \mathrm{wt} \%)$, $\mathrm{Al}_{2} \mathrm{O}_{3}(9.06-19.05 \mathrm{wt} \%)$, and relatively low $\mathrm{FeO}(0.26-1.98 \mathrm{wt} \%$, total iron), consistent with previous reports [57] (Table 1). They do not show systematically compositional difference between the form of veins and inclusions. X-ray single-crystal diffraction of the chrome chlorite grain confirms its crystal structure as a mineral of chlorite group, with its XRD data compared with chrome chlorites worldwide (Table 2 and Figure 3b). 
Table 1. Electron microprobe analyses (wt \%) of secondary hydrothermal phases in the Luobusa chromitites.

\begin{tabular}{|c|c|c|c|c|c|c|c|c|c|}
\hline \multirow{3}{*}{$\begin{array}{l}\text { Mineral: } \\
\text { Provenance: } \\
\text { Sample: }\end{array}$} & \multicolumn{5}{|c|}{ Chrome Chlorite } & \multirow{3}{*}{\multicolumn{2}{|c|}{$\begin{array}{c}\text { Calcite } \\
\text { This study } \\
\text { L6 }\end{array}$}} & \multirow{3}{*}{\multicolumn{2}{|c|}{$\begin{array}{c}\text { Dolomite } \\
\text { This study } \\
\text { L6 }\end{array}$}} \\
\hline & \multirow{2}{*}{\multicolumn{3}{|c|}{$\begin{array}{l}\text { This study } \\
\text { L6 and L7 }\end{array}$}} & \multicolumn{2}{|c|}{ Huang et al. [57] } & & & & \\
\hline & & & & KJchrXA & KJchr1XA & & & & \\
\hline \multirow{2}{*}{ Form: } & \multicolumn{3}{|c|}{ Vein and inclusion } & Vein & Inclusion & \multicolumn{4}{|c|}{ Euhedral crystal } \\
\hline & range $(n=11)$ & mean & std_err & mean $(n=9)$ & $n=1$ & 1 & 2 & 1 & 2 \\
\hline $\mathrm{Na}_{2} \mathrm{O}$ & $0.02-0.12$ & 0.05 & 0.03 & 0.02 & 0.00 & 0.00 & 0.03 & 0.03 & 0.03 \\
\hline $\mathrm{Cr}_{2} \mathrm{O}_{3}$ & $0.10-7.43$ & 4.72 & 1.90 & 5.08 & 5.30 & 0.00 & 0.00 & 0.02 & 0.00 \\
\hline $\mathrm{K}_{2} \mathrm{O}$ & $0.01-0.12$ & 0.03 & 0.03 & 0.01 & 0.02 & 0.00 & 0.01 & 0.01 & 0.00 \\
\hline $\mathrm{MgO}$ & $33.84-35.52$ & 34.26 & 0.44 & 32.56 & 30.31 & 0.16 & 0.11 & 23.30 & 22.03 \\
\hline $\mathrm{MnO}$ & $0.00-0.03$ & 0.01 & 0.01 & 0.02 & 0.00 & 0.02 & 0.00 & 0.00 & 0.00 \\
\hline $\mathrm{CaO}$ & $0.01-0.04$ & 0.02 & 0.01 & 0.03 & 0.04 & 59.78 & 58.70 & 28.91 & 30.19 \\
\hline $\mathrm{Al}_{2} \mathrm{O}_{3}$ & 9.06-19.05 & 11.85 & 2.44 & 11.20 & 12.84 & 0.00 & 0.00 & 0.00 & 0.00 \\
\hline $\mathrm{FeO}$ & $0.26-1.98$ & 0.77 & 0.55 & 0.77 & 0.66 & 0.06 & 0.04 & 0.03 & 0.00 \\
\hline $\mathrm{TiO}_{2}$ & $0.00-0.02$ & 0.01 & 0.01 & 0.06 & 0.06 & 0.01 & 0.00 & 0.03 & 0.00 \\
\hline $\mathrm{SiO}_{2}$ & $31.90-34.58$ & 33.15 & 0.78 & 33.11 & 30.88 & 0.00 & 0.03 & 0.00 & 0.00 \\
\hline $\mathrm{NiO}$ & $0.01-0.59$ & 0.37 & 0.20 & 0.42 & 0.50 & 0.00 & 0.02 & 0.01 & 0.00 \\
\hline $\mathrm{ZnO}$ & $0.00-0.06$ & 0.01 & 0.02 & & & 0.00 & 0.00 & 0.01 & 0.00 \\
\hline $\mathrm{H}_{2} \mathrm{O}$ & & & & 12.13 & 11.73 & & & & \\
\hline Total & $83.97-86.00$ & 85.25 & 0.70 & 95.41 & 92.34 & 60.03 & 58.94 & 52.33 & 52.25 \\
\hline
\end{tabular}

Table 2. Comparison of X-ray diffraction data of chrome chlorites.

\begin{tabular}{|c|c|c|c|c|c|}
\hline \multirow{2}{*}{\multicolumn{2}{|c|}{$\begin{array}{c}\text { X-ray Single-Crystal Diffraction } \\
\text { Luobusa (This Study) }\end{array}$}} & \multicolumn{4}{|c|}{ X-ray Powder Diffraction } \\
\hline & & \multicolumn{2}{|c|}{ Byrapur, India $b$} & \multicolumn{2}{|c|}{ California $^{b}$} \\
\hline d $(\AA ̊)$ & Intensity $^{a}$ & $\mathrm{~d}(\AA)$ & Intensity & d (̊̊) & Intensity \\
\hline 14.18 & & 14.25 & 39.5 & 14.15 & 37.0 \\
\hline 7.24 & & 7.19 & 96.0 & 7.11 & 95.2 \\
\hline 4.63 & & 4.79 & 92.0 & 4.741 & 92.6 \\
\hline 3.59 & & 4.58 & 4.0 & 4.581 & 7.0 \\
\hline 2.86 & & 3.91 & 4.0 & 3.931 & 2.0 \\
\hline 2.64 & & 3.59 & 93.5 & 3.561 & 93.5 \\
\hline 2.57 & & 2.86 & 26.5 & 2.847 & 24.9 \\
\hline 2.39 & & 2.58 & 11.0 & 2.583 & 5.7 \\
\hline 2.08 & & 2.53 & 3.0 & 2.538 & 9.3 \\
\hline 2.01 & & 2.42 & 6.0 & 2.44 & 7.2 \\
\hline 1.90 & & 2.33 & 3.0 & 2.377 & 4.1 \\
\hline 1.89 & & 2.26 & 4.0 & 2.322 & 2.0 \\
\hline 1.72 & & 2.04 & 3.5 & 2.26 & 3.3 \\
\hline 1.67 & & 2.01 & 3.0 & 2.033 & 7.1 \\
\hline 1.58 & & 2.00 & 3.0 & 2.003 & 7.9 \\
\hline 1.55 & & 1.87 & 3.5 & 1.883 & 3.2 \\
\hline 1.51 & & 1.84 & 5.0 & 1.825 & 2.9 \\
\hline 1.42 & & 1.72 & 4.0 & 1.803 & 1.5 \\
\hline 1.33 & & 1.62 & 3.0 & 1.711 & 1.3 \\
\hline \multirow[t]{6}{*}{1.29} & & 1.57 & 7.0 & 1.666 & 1.8 \\
\hline & & 1.50 & 9.0 & 1.569 & 6.0 \\
\hline & & 1.49 & 2.5 & 1.537 & 6.1 \\
\hline & & 1.52 & 2.8 & 1.501 & 2.3 \\
\hline & & & & 1.425 & 2.8 \\
\hline & & & & 1.396 & 5.7 \\
\hline
\end{tabular}

\footnotetext{
a The intensities of the corresponding d-spacing of single-crystal chrome chlorite were not determined in this study. ${ }^{b}$ Data of X-ray powder diffraction of chrome chlorites from Byrapur and California are adopted from Damodaran and Somasekar [32].
} 


\section{2. ${ }^{40} \mathrm{Ar} /{ }^{39} \mathrm{Ar}$ Age}

Two aliquots of each sample (L6 and L7) were measured for argon isotopes. Unfortunately, only one aliquot of sample L7 yielded reliable age information (Figure 4). The remaining three aliquots failed to give ${ }^{40} \mathrm{Ar} /{ }^{39} \mathrm{Ar}$ ages due to inadequate argon concentrations that were overwhelmed by high concentrations of gaseous impurities, most likely $\mathrm{H}_{2} \mathrm{O}, \mathrm{CO}_{2}$, and hydrocarbons etc. The ${ }^{40} \mathrm{Ar} /{ }^{39} \mathrm{Ar}$ data of the successful aliquot of sample L7 are listed in Table 3. The sample yielded much older apparent ages in the first three steps and slightly older apparent ages in the last two steps, forming an age plateau in steps $4-10$ with an age of $29.88 \pm 0.42 \mathrm{Ma}\left(\mathrm{MSWD}=0.12\right.$, plateau $\left.{ }^{39} \mathrm{Ar}=74.6 \%\right)$ (Figure 4a). The plateau data points define a concordant inverse isochron age of $30.15 \pm 1.05 \mathrm{Ma}$ $\left(\mathrm{MSWD}=0.08\right.$, initial ${ }^{40} \mathrm{Ar} /{ }^{36} \mathrm{Ar}=295.8 \pm 9.7$ ) (Figure $\left.4 \mathrm{~b}\right)$. Uncertainties of the ages reported here are internal error $(2 \sigma)$, including uncertainties propagated from analytical errors, and $J$-value.
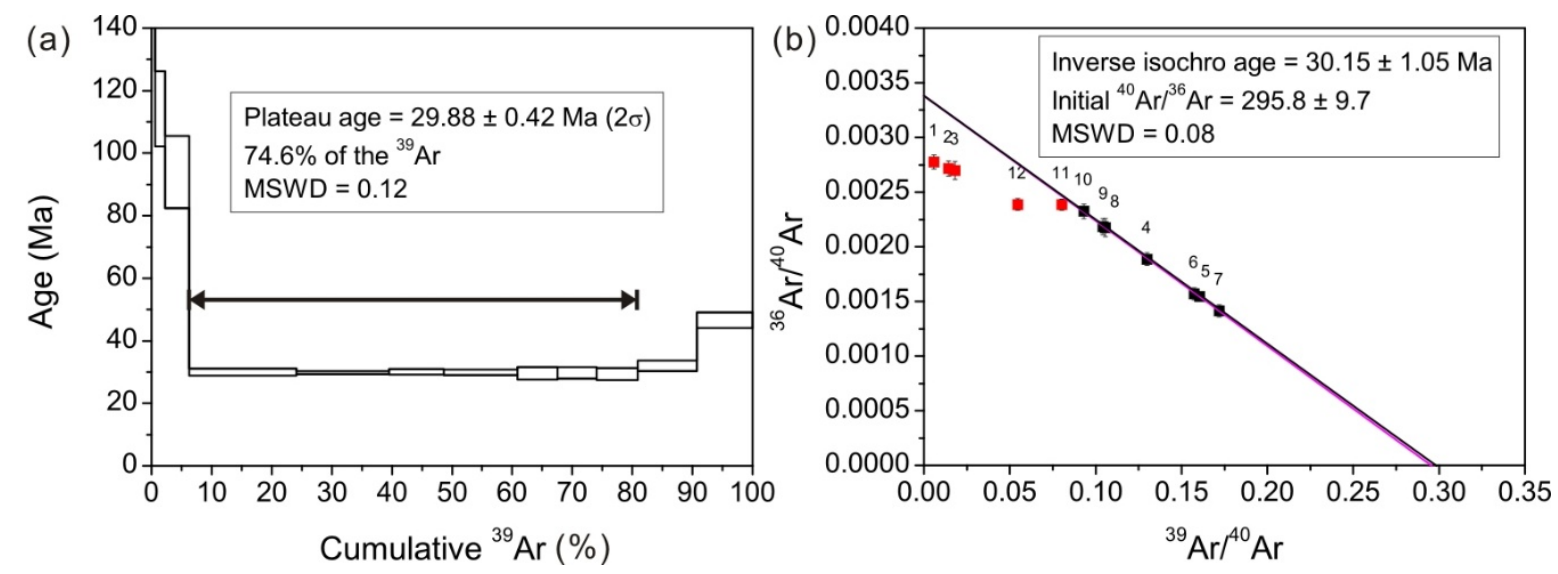

Figure 4. (a) Age spectrum of the chrome chlorite separates from the successful aliquot of sample L7. (b) Inverse isochron plot of ${ }^{36} \mathrm{Ar} /{ }^{40} \mathrm{Ar}$ vs. ${ }^{39} \mathrm{Ar} /{ }^{40} \mathrm{Ar}$.

Table 3. The ${ }^{40} \mathrm{Ar} /{ }^{39} \mathrm{Ar}$ laser stepwise-heating data of chrome chlorites from the successful aliquot of sample L7.

\begin{tabular}{|c|c|c|c|c|c|c|c|c|}
\hline Step & $\begin{array}{c}\text { Laser } \\
\text { Power } \\
(\%)\end{array}$ & $\begin{array}{c}{ }^{39} \mathrm{Ar} \\
\mathrm{Cum} . \\
(\%)\end{array}$ & $\begin{array}{c}{ }^{40} \mathrm{Ar}^{*} \\
(\%)\end{array}$ & $\begin{array}{c}{ }^{39} \mathrm{Ar} /{ }^{40} \mathrm{Ar} \pm \\
2 \sigma\left(10^{-2}\right)\end{array}$ & $\begin{array}{c}{ }^{36} \mathrm{Ar} /{ }^{40} \mathrm{Ar} \pm \\
2 \sigma\left(10^{-3}\right)\end{array}$ & $\begin{array}{c}{ }^{40} \mathrm{Ar}^{*} /{ }^{39} \mathrm{Ar} \\
\pm 2 \sigma\end{array}$ & $\begin{array}{l}\text { Apparent Age } \\
\pm 2 \sigma(\mathrm{Ma})\end{array}$ & $\mathrm{K} / \mathrm{Ca}$ \\
\hline 2 & 3.2 & 1.63 & 18.93 & $1.44 \pm 0.01$ & $2.72 \pm 0.07$ & $13.12 \pm 1.42$ & $114.14 \pm 12.01$ & 0.23 \\
\hline 3 & 3.6 & 4.04 & 19.51 & $1.82 \pm 0.01$ & $2.70 \pm 0.08$ & $10.74 \pm 1.35$ & $93.96 \pm 11.54$ & 0.27 \\
\hline 4 & 4.0 & 17.83 & 43.70 & $12.99 \pm 0.05$ & $1.89 \pm 0.06$ & $3.36 \pm 0.13$ & $29.97 \pm 1.18$ & 0.22 \\
\hline 7 & 5.6 & 12.24 & 57.75 & $17.19 \pm 0.07$ & $1.41 \pm 0.06$ & $3.36 \pm 0.10$ & $29.93 \pm 0.86$ & 0.24 \\
\hline 8 & 6.4 & 6.62 & 35.04 & $10.56 \pm 0.05$ & $2.18 \pm 0.08$ & $3.32 \pm 0.23$ & $29.56 \pm 2.05$ & 0.20 \\
\hline 9 & 7.0 & 6.52 & 34.82 & $10.42 \pm 0.05$ & $2.18 \pm 0.07$ & $3.34 \pm 0.21$ & $29.77 \pm 1.84$ & 0.17 \\
\hline 10 & 8.0 & 6.82 & 30.61 & $9.30 \pm 0.04$ & $2.32 \pm 0.07$ & $3.29 \pm 0.21$ & $29.32 \pm 1.90$ & 0.17 \\
\hline 11 & 10.0 & 9.86 & 28.81 & $8.02 \pm 0.03$ & $2.38 \pm 0.05$ & $3.59 \pm 0.19$ & $31.97 \pm 1.69$ & 0.08 \\
\hline 12 & 15.0 & 9.28 & 28.72 & $5.47 \pm 0.02$ & $2.39 \pm 0.05$ & $5.25 \pm 0.29$ & $46.57 \pm 2.54$ & 0.05 \\
\hline
\end{tabular}

\section{Discussion}

\subsection{Argon Release Pattern}

The argon release pattern from the successful aliquot of sample L7 displays older apparent ages in the first three and last two steps, whereas younger consistent apparent ages are expressed in the intermediate steps.

The reason for higher initial ages likely results from inaccurately determined ${ }^{39} \mathrm{Ar}$ and ${ }^{40} \mathrm{Ar}^{*}$ (radiogenic ${ }^{40} \mathrm{Ar}$ ) in the early stages of gas release. It is notable that the concentrations of released 
${ }^{39} \mathrm{Ar}$ and ${ }^{40} \mathrm{Ar}$ were insufficient in the initial thermal steps. For example, only 0.6 and $1.6 \%$ of ${ }^{39} \mathrm{Ar}$ were released in the first and second step, respectively, and ${ }^{40} \mathrm{Ar}^{*}$ was less than $20 \%$ of total ${ }^{40} \mathrm{Ar}$ in each initial three steps (Table 3, Figure 4a). The low concentration of released ${ }^{39} \mathrm{Ar}$ and ${ }^{40} \mathrm{Ar}^{*}$ may introduce large errors in the determination of age, as they are key parameters $\left({ }^{40} \mathrm{Ar} *{ }^{* 39} \mathrm{Ar}\right.$ ratio) in the calculation, especially when the measured ${ }^{39} \mathrm{Ar}$ is very low. Thus, the high initial apparent ages (250 \pm 26 Ma for step 1, $114 \pm 12$ Ma for step 2, and $94 \pm 12$ Ma for step 3) are most probably ascribed to the inability to precisely determine the released ${ }^{39} \mathrm{Ar}$ and ${ }^{40} \mathrm{Ar}{ }^{*}$ in those steps.

As for the last two steps, the effect of inadequate correction for high-temperature blanks should be considered as one most possible reason for obtaining higher apparent ages. Because procedure blanks at high-temperature steps are always high resulting in the inaccurate determination of measured argon (e.g., [74]). This effect is remarkable especially for samples with lower gas amounts, like the ones in this study. Despite the higher apparent ages observed in the first three and last two heating steps, a prominent age plateau consistent with a calculated isochron age is apparent and its significance will be discussed in the following sections.

\subsection{Reliability of the Age}

The most challenging part for Ar/Ar dating of chrome chlorites is that they are not typical $\mathrm{K}$-bearing minerals. Potassium is not preferentially accommodated in the structure of chlorite. So chlorites generally have trace or undetectable $\mathrm{K}$ contents. That means the contents of radiogenic $\mathrm{Ar}$ produced by potassium in chlorites may hardly meet the detectable limit of the Ar/ $\mathrm{Ar}$ machine in short geological time. Nevertheless, early attempts for Ar/Ar dating of chlorite show that careful selection and preparation of the chlorite samples with elevated $\mathrm{K}$ contents (ca. $0.1 \mathrm{wt} \% \mathrm{~K}_{2} \mathrm{O}$ ) can give geologically meaningful ages [36].

Based on the EMPA data of the chrome chlorites and the dated age, we did simulative calculations to test the reliability of the age. We adopt that the chrome chlorites contain 83-996 ppm K, corresponding to the measured $0.01-0.12$ wt $\% \mathrm{~K}_{2} \mathrm{O}$ (this may a lower-limit of estimate as the oxide weight percent is not normalized to a $100 \%$ total). Then $12 \mathrm{mg}$ chrome chlorites can produce $6.39 \times 10^{-15}-6.13 \times 10^{-14} \mathrm{~mol}^{40} \mathrm{Ar}^{*}$ in 30 million years assuming no loss of argon, calculated by using the argon production equation given by Ballentine and Burnard [75]. Meanwhile, we calculated the amounts of ${ }^{40} \mathrm{Ar}^{*}$ (radiogenic fraction) measured on the successful aliquot of sample L7. It gives $3.86 \times 10^{-14} \mathrm{~mol}^{40} \mathrm{Ar}^{*}$ as a sum from steps 4 to 10 . The ${ }^{40} \mathrm{Ar}^{*}$ produced in first 3 and last 2 heating steps are not included (if included, the measured ${ }^{40} \mathrm{Ar}^{*}$ will be $6.44 \times 10^{-14} \mathrm{~mol}$ ) due to inadequate releasing and correction of ${ }^{40} \mathrm{Ar}^{*}$, as discussed above. We note that the amounts of measured ${ }^{40} \mathrm{Ar}^{*}$ are in the range or match the high end-member of that predicted by $\mathrm{K}$ contents of the chrome chlorites. This illustrates that the potassium in the chrome chlorites, despite their trace amount, can account for the measured ${ }^{40} \mathrm{Ar}^{*}$. It also gives reasonable explanations for the failure of the other 3 aliquots, as the $\mathrm{K}$ contents of these aliquots may be too low to produce enough ${ }^{40} \mathrm{Ar}^{*}$ which can be precisely determined by the present machines. Thus, we conclude that the age is reliable and represents the age of hydrothermal activity.

\subsection{Ma Magmatism in Southern Tibet}

The age of the chrome chlorites ( $30 \mathrm{Ma})$ in this study is in agreement with the age of the adakite-like granitoids exposed in the northeastern Zedong area (e.g., [43,45,47,48]), located tens of kilometres west of Luobusa (Figure 1b).

Igneous activity at $\sim 30 \mathrm{Ma}$ was first recognized following ion microprobe dating of zircons collected from the Yaja granodiorite in Zedong, for which a crystallization age of $30.4 \pm 0.4$ Ma was determined [45]. This age was later confirmed by Chung et al. [43] using a sensitive high-resolution ion microprobe (SHRIMP). Coeval granitic intrusions were also found in other locations around the Yaja granodiorite (Figure 1b) and dated by Ar-Ar and zircon U-Pb methods [46-50,76]. The geochemical compositions of these plutons show adakitic affinities, with high $\mathrm{SiO}_{2}, \mathrm{~K}_{2} \mathrm{O}$, and $\mathrm{Sr}$, but low $\mathrm{Y}$ and $\mathrm{Yb}$ 
contents $[43,47,49,50,61]$. Combined with other Late Oligocene-Miocene (ca. 26-10 Ma) adakites widely distributed on the south edge of Lhasa terrane $[42,61,65,66,77]$, the intrusions were interpreted to have been generated in a post-collisional setting in response to the continued convergence between India and Asia [43]. Nevertheless, the source, or petrogenesis, of the adakitic magma and the corresponding geodynamic mechanism are still under debate.

As a result of interaction between these adakitic intrusions and the wall rocks (the Bima Group, mainly containing interbedded carbonate rock and siltstone), extensive porphyry-skarn mineralization of $\mathrm{Cu}-\mathrm{Au} \pm$ Mo were formed during the late Oligocene to early Miocene (ca. 30-24 Ma) (e.g., [48,78]). Alterations of the skarn-type mineralization mainly include an early stage of skarn and a late silicate stage of sericitization, silicification and chloritization. Fluid inclusion thermometry of the late stage quartz suggests a homogenization temperature of $232-298{ }^{\circ} \mathrm{C}$ for gas-liquid or liquid phase and $330-335{ }^{\circ} \mathrm{C}$ for a few $\mathrm{CO}_{2}$ inclusions [48].

\subsection{Formation of the Hydrothermal Minerals and Source of the Fluids}

Chlorite is a common mineral found in low-grade metamorphic and hydrothermally altered rocks; and it can either replace pre-existing minerals or precipitate directly from solution (e.g., [79]). The more common Fe-Mg chlorite is usually formed at low temperatures (ca. $<300{ }^{\circ} \mathrm{C}$ ) [79], but the pinkish chrome chlorite in this study seems to be formed at a relatively higher temperature like $\sim 300{ }^{\circ} \mathrm{C}$ as chromium in podiform chromitites and associated mafic/ultramafic rocks would be mobilized over a range of $300-500{ }^{\circ} \mathrm{C}$ [34]. This is consistent with the estimation of fluid temperatures of at least $300{ }^{\circ} \mathrm{C}$ in the Luobusa listwanites [27]. We note that in our massive chromitites L6 and L7, the chromites were not intensively altered to be ferritchromites around the contact with chrome chlorites. This may due to low fluid/chromite ratios in the process of hydrothermal alteration. As an inference, some part of chromium incorporated into the chlorites may come from adjacent listwanites where chromian spinels were more altered to lose their chromium [28].

In addition to the chrome chlorites, another group of hydrothermal minerals in the massive chromitites are carbonates. In the carbonate veins of L6, we found abundant calcite and dolomite (Figure 2c, d, and Table 1). Although CaO-rich minerals are not common in the Luobusa listwanites, they do exist [27]. The source of $\mathrm{CaO}$ may come from the adjacent flysch sediments when the $\mathrm{CO}_{2}$-rich hydrothermal fluids circulated through them [27]. As to the $\mathrm{CO}_{2}$-rich hydrothermal fluids, we argue that they are most likely to be linked with the $\sim 30$ Ma magmatic intrusions based on the hydrothermal age determined in this study and the fluid characteristics discussed above.

Although previous studies have reported detailed mineralogy, petrography, and geochemistry of the Luobusa listwanites and their adjacent peridotites [27,28], the source of the hydrothermal fluids still remains unclear and the origin of the listwanites is under debate.

The Luobusa listwanites are compared with the Sartohay (Xinjiang, China) listwanites which are spatially related to granitic plutons. The listwanites from both places are almost identical mineralogically and have similar fluid temperatures of $\geq 300^{\circ} \mathrm{C}$ [27]. From this point of view, the fluid source of the Luobusa listwanites may also be related to plutons, even though the scale of hydrothermal systems from the two places appear to be different. However, any reasonable intrusive activity resulting in the formation of the listwanites was not found or reported so far in Luobusa. Granitoids found in the study area are biotite granites and quartz diorites from the Gangdese batholith [28]. These plutonic rocks were dated as Late Cretaceous in age and are thought to predate the emplacement of the Luobusa ophiolite [28]. They cannot be the source of the hydrothermal fluids because the listwanites were clearly formed after the emplacement of the ophiolite $[27,28]$.

In contrast, Liang et al. [80] proposed that the listwanites could be interactive products between mantle peridotites and Triassic flysch during the emplacement of the ophiolite over the Indian continental margin (probably occurring at an initial collision stage, ca. 65-55 Ma). In this model, the heat responsible for the medium-high temperature deformation and fabric is derived from the 
"hot" peridotite itself and/or shearing friction [80]. However, there is no age constraint to test such a hypothesis in their study.

Determination of the hydrothermal age is very important to clarify the source of the fluids and the origin of the listwanites. Based on the agreement of the age of chrome chlorites found in massive chromitites in this study with the age of granitic intrusions and associated mineralization around the study area, it is suggested that the Luobusa listwanites may have a genetic relationship with the plutonism that occurred at $\sim 30 \mathrm{Ma}$. In other words, the hydrothermal fluids circulating through the chromitites and peridotites were probably derived directly or indirectly from the intrusion and evolution of granitoids during the late Oligocene, even though the associated plutons have not been found or reported in Luobusa.

\subsection{Possible Circulating Ways of the Fluids}

There are two possible passages for circulating hydrothermal fluids: transverse dominated and vertical dominated, for simplification. In the former case, assuming that there are no $~ 30$ Ma intrusive rocks in the Luobusa area, the fluids most probably come from the nearest adakitic intrusions west of Luobusa. The nearest reported pluton is the Sangri granodiorite, which intruded the rocks of the Yarlung-Zangbo suture zone and has a crystallization age of $29.6 \pm 0.4 \mathrm{Ma}$ (Figure 1b) [49]. Thick Cretaceous sedimentary rocks in the area, especially siltstone and tuff, can effectively obstruct hydrothermal fluids and result in lateral flow, as indicated by the linear distribution of hydrothermal mineralization [76]. Moreover, the tectonic contact between the suture zone and the Indian plate also would have facilitated the passage of fluids. The facts that the hydrothermal fluids forming the Luobusa listwanites were clearly restricted to the fault zone, and the listwanites are linearly distributed with not a large scale seem to support this case.

However, there are some limitations or problems which cannot be solved by the present study. For example, most post-collisional adakitic granitoids are exposed as small-volume plugs or dikes/sills intruding the Gangdese batholith $[43,61]$. Whether these small intrusions can generate so large a volume of hydrothermal fluids to influence a location more than $20 \mathrm{~km}$ away needs further simulations. In addition, if the hydrothermal fluids which altered the Luobusa chromitites and peridotites come from remote intrusions like the Sangri granodiorite, then the degree of alteration should become weak gradually from west to east. But this trend is not observed. Conversely, listwanites from the Kangjinla district in the east are more developed than from the Luobusa district in the west [28].

In the latter case, it is suggested that there could be similar adakitic intrusives in the local Luobusa area, which provided hydrothermal fluids that altered fresh or serpentinized peridotites into listwanites and intruded the massive chromitites. On the basis of the linear distribution of post-collisional adakitic intrusions along the south edge of Gangdese batholith, and especially the fact that the late Oligocene plutonism occurred extensively in the Zedong area $[43,45-50,76]$ west of Luobusa and in the Gyaca area east of Luobusa, it is reasonable to speculate the existence of coeval plutonism in the local Luobusa area. The newly found gold enrichment in the Luobusa listwanites [28] also supports such a speculation, which may extend the Kelu-Liebu-Chongmuda ore-forming sub-belt father to the east.

If the latter case is correct, then a followed question to answer is why the intrusives are not exposed. The most likely explanation is that they are probably covered by the Luobusa ophiolite and the late Oligocene-early Miocene molasse deposits (the Luobusa Formation). Thermochronological studies suggest a rapid cooling of the GT hanging wall rocks along strike from Yaja to the west during the late Oligocene to early Miocene, which is typical of tectonic denudation owing to slip on the GT. The cooling rates in the eastern portion of Zedong area are much lower probably due to erosional denudation of a topographic high [45]. The differential exposure history along strike of GT, coupled with possible high topography, may lead to less denudation of the Gangdese batholith in Luobusa. In addition, the occurrence of the Renbu-Zedong Thrust (RZT), part of the Great Count Thrust (GCT) system that was active between 19 and $10 \mathrm{Ma}[45,81,82]$, may further prevent denudation of the intrusives of interest. The RZT system seems to have thrust farther to the north in Luobusa 
and obscured the thermal history in the hanging wall of early GT [45], not forming the "Thrust Window" as in Zedong. Accordingly, the speculated 30 Ma plutons in Luobusa may be buried by a northward-verging imbricate system composed of the Luobusa ophiolite and its overlying and underlying units [51].

\section{Conclusive Summary and Implications}

The Luobusa chromitites recorded a $~ 30$ Ma hydrothermal event as indicated by ${ }^{40} \mathrm{Ar} /{ }^{39} \mathrm{Ar}$ dating of chrome chlorites derived from hydrothermal alteration. The Ar release pattern shows no evidence of cooling history or later reheated degassing and the measured ${ }^{40} \mathrm{Ar}^{*}$ matches predicted by $\mathrm{K}$ contents of the chrome chlorites, thus it represents the age of chrome chlorites formed by hydrothermal alteration processes. Based on the agreement of this hydrothermal age with the $\sim 30 \mathrm{Ma}$ age of adakitic plutons exposed in Zedong area and the extensive late Oligocene plutonism distributed along southeastern Gangdese, it is suggested that the hydrothermal alteration was related to the $\sim 30$ Ma igneous activity. The hydrothermal age constraint not only provides a possible interpretation for the Luobusa listwanites, but also probably extends the $\sim 30 \mathrm{Ma}$ post-collisional magmatism and probably associated $\mathrm{Cu}-\mathrm{Au}$ mineralization further east from the Zedong area.

We note that the limitation of this work is that only a single meaningful age was obtained. In future research, efforts should be made for exploring the inferred 30 Ma plutons and possible $\mathrm{Cu}-\mathrm{Au}$ mineralization in Luobusa area and obtaining more data of the hydrothermal age even though successful dating of chrome chlorites is difficult. Based on this study, it is suggested that chrome chlorites with elevated potassium contents (ca. $\mathrm{K}_{2} \mathrm{O}$ wt \% reaches 0.1 ) and prolonged geological age (ca. $\geq 30 \mathrm{Ma}$ ) can be potentials for Ar/Ar dating, through which the age of hydrothermal activity can be obtained.

Author Contributions: Conceptualization, W.G. and H.H.; Formal analysis, W.G., Y.L. and F.S.; Funding acquisition, H.H.; Investigation, X.B.; Resources, Y.L.; Supervision, H.H. and R.Z.; Validation, H.H.; Visualization, W.G.; Writing-original draft, W.G.

Funding: This research was funded by the National Natural Science Foundation of China (grant number 41425013) and the National Key R\&D Program of China (grant number 2016YFC0600105).

Acknowledgments: We thank Hui Li for his assistance on single-crystal XRD analysis of chrome chlorite. We are grateful to Bill Griffin for discussion and his constructive suggestions. We thank the anonymous reviewers for their constructive comments and suggestions. We are grateful to the editors of Minerals for their efficient and professional handling of the manuscript.

Conflicts of Interest: The authors declare no conflict of interest.

\section{References}

1. Guo, W.; He, H.; Hilton, D.R.; Zheng, Y.; Su, F.; Liu, Y.; Zhu, R. Recycled noble gases preserved in podiform chromitites from Luobusa, Tibet. Chem. Geol. 2017, 469, 97-109. [CrossRef]

2. Su, B.X.; Zhou, M.F.; Robinson, P.T. Extremely large fractionation of Li isotopes in a chromitite-bearing mantle sequence. Sci. Rep. 2016, 6, 22370. [CrossRef] [PubMed]

3. Xiao, Y.; Teng, F.Z.; Su, B.X.; Hu, Y.; Zhou, M.F.; Zhu, B.; Shi, R.D.; Huang, Q.S.; Gong, X.H.; He, Y.S. Iron and magnesium isotopic constraints on the origin of chemical heterogeneity in podiform chromitite from the Luobusa ophiolite, Tibet. Geochem. Geophys. Geosyst. 2016, 17, 940-953. [CrossRef]

4. Xiong, F.H.; Yang, J.S.; Robinson, P.T.; Xu, X.Z.; Liu, Z.; Li, Y.; Li, J.Y.; Chen, S.Y. Origin of podiform chromitite, a new model based on the Luobusa ophiolite, Tibet. Gondwana Res. 2015, 27, 525-542. [CrossRef]

5. Xu, X.Z.; Yang, J.S.; Ba, D.Z.; Guo, G.L.; Robinson, P.T.; Li, J.Y. Petrogenesis of the Kangjinla peridotite in the Luobusa ophiolite, Southern Tibet. J. Asian Earth Sci. 2011, 42, 553-568. [CrossRef]

6. Zhou, M.F.; Robinson, P.T.; Malpas, J.; Edwards, S.J.; Qi, L. REE and PGE geochemical constraints on the formation of dunites in the Luobusa ophiolite, Southern Tibet. J. Petrol. 2005, 46, 615-639. [CrossRef]

7. Zhou, M.F.; Robinson, P.T.; Malpas, J.; Li, Z.J. Podiform chromitites in the Luobusa ophiolite (Southern Tibet): Implications for melt-rock interaction and chromite segregation in the upper mantle. J. Petrol. 1996, 37, 3-21. [CrossRef] 
8. Zhou, M.F.; Robinson, P.T.; Su, B.X.; Gao, J.F.; Li, J.W.; Yang, J.S.; Malpas, J. Compositions of chromite, associated minerals, and parental magmas of podiform chromite deposits: The role of slab contamination of asthenospheric melts in suprasubduction zone environments. Gondwana Res. 2014, 26, 262-283. [CrossRef]

9. Bai, W.J.; Zhou, M.F.; Robison, P.T.; Fang, Q.S.; Yan, B.G.; Zhang, Z.M.; Hu, X.F.; Yang, J.S. Origin of Podiform Chromitites, Diamonds and Associated Mineral Assemblage in the Luobusa Ophiolite, Tibet; Seismological Press: Beijing, China, 2000; p. 98, (In Chinese with English abstract).

10. Griffin, W.L.; Afonso, J.C.; Belousova, E.A.; Gain, S.E.; Gong, X.H.; Gonzalez-Jimenez, J.M.; Howell, D.; Huang, J.X.; McGowan, N.; Pearson, N.J.; et al. Mantle recycling: Transition zone metamorphism of Tibetan ophiolitic peridotites and its tectonic implications. J. Petrol. 2016, 57, 655-684. [CrossRef]

11. Howell, D.; Griffin, W.L.; Yang, J.; Gain, S.; Stern, R.A.; Huang, J.X.; Jacob, D.E.; Xu, X.; Stokes, A.J.; O'Reilly, S.Y.; et al. Diamonds in ophiolites: Contamination or a new diamond growth environment? Earth Planet. Sci. Lett. 2015, 430, 284-295. [CrossRef]

12. McGowan, N.M.; Griffin, W.L.; González-Jiménez, J.M.; Belousova, E.; Afonso, J.C.; Shi, R.; McCammon, C.A.; Pearson, N.J.; O’Reilly, S.Y. Tibetan chromitites: Excavating the slab graveyard. Geology 2015, 43, 179-182. [CrossRef]

13. Robinson, P.T.; Bai, W.J.; Malpas, J.; Yang, J.S.; Zhou, M.F.; Fang, Q.S.; Hu, X.F.; Cameron, S.; Staudigel, H. Ultra-high pressure minerals in the Luobusa Ophiolite, Tibet, and their tectonic implications. Geol. Soc. Lond. Spec. Publ. 2004, 226, 247-271. [CrossRef]

14. Robinson, P.T.; Trumbull, R.B.; Schmitt, A.; Yang, J.S.; Li, J.W.; Zhou, M.F.; Erzinger, J.; Dare, S.; Xiong, F.H. The origin and significance of crustal minerals in ophiolitic chromitites and peridotites. Gondwana Res. 2015, 27, 486-506. [CrossRef]

15. Shi, R.D.; Alard, O.; Zhi, X.C.; O’Reilly, S.Y.; Pearson, N.J.; Griffin, W.L.; Zhang, M.; Chen, X.M. Multiple events in the Neo-Tethyan oceanic upper mantle: Evidence from Ru-Os-Ir alloys in the Luobusa and Dongqiao ophiolitic podiform chromitites, Tibet. Earth Planet. Sci. Lett. 2007, 261, 33-48. [CrossRef]

16. Xu, X.Z.; Yang, J.S.; Chen, S.Y.; Fang, Q.S.; Bai, W.J.; Ba, D.Z. Unusual mantle mineral group from chromitite orebody Cr-11 in Luobusa ophiolite of Yarlung-Zangbo suture zone, Tibet. J. Earth Sci. 2009, 20, $284-302$. [CrossRef]

17. Xu, X.Z.; Yang, J.S.; Robinson, P.T.; Xiong, F.H.; Ba, D.Z.; Guo, G.L. Origin of ultrahigh pressure and highly reduced minerals in podiform chromitites and associated mantle peridotites of the Luobusa ophiolite, Tibet. Gondwana Res. 2015, 27, 686-700. [CrossRef]

18. Yamamoto, S.; Komiya, T.; Hirose, K.; Maruyama, S. Coesite and clinopyroxene exsolution lamellae in chromites: In-situ ultrahigh-pressure evidence from podiform chromitites in the Luobusa ophiolite, southern Tibet. Lithos 2009, 109, 314-322. [CrossRef]

19. Yang, J.S.; Dobrzhinetskaya, L.; Bai, W.J.; Fang, Q.S.; Robinson, P.T.; Zhang, J.; Green, H.W. Diamond- and coesite-bearing chromitites from the Luobusa ophiolite, Tibet. Geology 2007, 35, 875-878. [CrossRef]

20. Yang, J.S.; Meng, F.C.; Xu, X.Z.; Robinson, P.T.; Dilek, Y.; Makeyev, A.B.; Wirth, R.; Wiedenbeck, M.; Cliff, J. Diamonds, native elements and metal alloys from chromitites of the Ray-Iz ophiolite of the Polar Urals. Gondwana Res. 2015, 27, 459-485. [CrossRef]

21. Yang, J.S.; Robinson, P.T.; Dilek, Y. Diamonds in Ophiolites. Elements 2014, 10, 127-130. [CrossRef]

22. Farahat, E.S. Chrome-spinels in serpentinites and talc carbonates of the El Ideid-El Sodmein District, central Eastern Desert, Egypt: Their metamorphism and petrogenetic implications. Chem. Erde 2008, 68, 193-205. [CrossRef]

23. Merlini, A.; Grieco, G.; Diella, V. Ferritchromite and chromian-chlorite formation in mélange-hosted Kalkan chromitite (Southern Urals, Russia). Am. Mineral. 2009, 94, 1459-1467. [CrossRef]

24. Satsukawa, T.; Piazolo, S.; González-Jiménez, J.M.; Colás, V.; Griffin, W.L.; O’Reilly, S.Y.; Gervilla, F.; Fanlo, I.; Kerestedjian, T.N. Fluid-present deformation aids chemical modification of chromite: Insights from chromites from Golyamo Kamenyane, SE Bulgaria. Lithos 2015, 228-229, 78-89. [CrossRef]

25. Azer, M.K. Evolution and economic significance of listwaenites associated with Neoproterozoic ophiolites in South eastern Desert, Egypt. Geol. Acta 2013, 11, 113-128.

26. Hansen, L.D.; Dipple, G.M.; Gordon, T.M.; Kellett, D.A. Carbonated serpentinite (listwanite) at Atlin, British Columbia: A geological analogue to carbon dioxide sequestration. Can. Mineral. 2005, 43, 225-239. [CrossRef]

27. Robinson, P.T.; Malpas, J.; Zhou, M.F.; Ash, C.; Yang, J.S.; Bai, W.J. Geochemistry and origin of listwanites in the Sartohay and Luobusa ophiolites, China. Int. Geol. Rev. 2005, 47, 177-202. [CrossRef] 
28. Zhang, L.; Yang, J.S.; Robinson, P.T.; Xiong, F.; Chen, Y.H.; Lai, S.M.; Chen, M. Origin of listwanite in the Luobusa ophiolite, Tibet, implications for chromite stability in hydrothermal systems. Acta Geol. Sin. (Engl. Ed.) 2015, 89, 402-417.

29. Qiu, T.; Zhu, Y. Geology and geochemistry of listwaenite-related gold mineralization in the Sayi gold deposit, Xinjiang, NW China. Ore Geol. Rev. 2015, 70, 61-79. [CrossRef]

30. Rajendran, S.; Nasir, S.; Kusky, T.M.; Ghulam, A.; Gabr, S.; El-Ghali, M.A.K. Detection of hydrothermal mineralized zones associated with listwaenites in Central Oman using ASTER data. Ore Geol. Rev. 2013, 53, 470-488. [CrossRef]

31. Ucurum, A.; Larson, L.T. Geology, base-precious metal concentration and genesis of the silica-carbonate alteration (listwaenites) from late Cretaceous ophiolitic melanges at central east Turkey. Chem. Erde 1999, 59, 77-104.

32. Damodaran, K.T.; Somasekar, B. Chrome Chlorite (Kotschubeite) from the Nuggihalli Schist Belt. Clays Clay Miner. 1976, 24, 31-35. [CrossRef]

33. Lapham, D.M. Structural and chemical variation in chrome chlorite. Am. Mineral. 1958, 43, 921-956.

34. Franklin, B.J.; Marshall, B.; Graham, I.T.; McAndrew, J. Remobilization of PGE in podiform chromitite in the Coolac Serpentinite Belt, Southeastern Australia. Aust. J. Earth Sci. 1992, 39, 365-371. [CrossRef]

35. Hatipoğlu, M.; Oğuzer, M.B.; Baki Buzlu, H. Gemmological and mineralogical investigations and genesis of the kammererite from the Keşiş (Erzincan) and Kop (Erzurum) mountains. J. Afr. Earth Sci. 2013, 84, $20-35$. [CrossRef]

36. Alexandre, P.; Kyser, K.; Thomas, D.; Polito, P.; Marlat, J. Geochronology of unconformity-related uranium deposits in the Athabasca Basin, Saskatchewan, Canada and their integration in the evolution of the basin. Miner. Deposita 2007, 44, 41. [CrossRef]

37. Bai, X.-J.; Qiu, H.-N.; Liu, W.-G.; Mei, L.-F. Automatic ${ }^{40} \mathrm{Ar} /{ }^{39} \mathrm{Ar}$ Dating Techniques Using Multicollector ARGUS VI Noble Gas Mass Spectrometer with Self-Made Peripheral Apparatus. J. Earth Sci. 2018, 29, 408-415. [CrossRef]

38. Matchan, E.L.; Phillips, D. High precision multi-collector ${ }^{40} \mathrm{Ar} /{ }^{39} \mathrm{Ar}$ dating of young basalts: Mount Rouse volcano (SE Australia) revisited. Quat. Geochronol. 2014, 22, 57-64. [CrossRef]

39. Allègre, C.J.; Courtillot, V.; Tapponnier, P.; Hirn, A.; Mattauer, M.; Coulon, C.; Jaeger, J.J.; Achache, J.; Scharer, U.; Marcoux, J.; et al. Structure and evolution of the Himalaya-Tibet orogenic belt. Nature 1984, 307, 17-22. [CrossRef]

40. Yin, A.; Harrison, T.M. Geologic Evolution of the Himalayan-Tibetan Orogen. Annu. Rev. Earth Planet. Sci. 2000, 28, 211-280. [CrossRef]

41. Aitchison, J.C.; Davis, A.M.; Liu, J.; Luo, H.; Malpas, J.G.; McDermid, I.R.C.; Wu, H.; Ziabrev, S.V.; Zhou, M.-F. Remnants of a Cretaceous intra-oceanic subduction system within the Yarlung-Zangbo suture (southern Tibet). Earth Planet. Sci. Lett. 2000, 183, 231-244. [CrossRef]

42. Hou, Z.Q.; Gao, Y.F.; Qu, X.M.; Rui, Z.Y.; Mo, X.X. Origin of adakitic intrusives generated during mid-Miocene east-west extension in southern Tibet. Earth Planet. Sci. Lett. 2004, 220, 139-155. [CrossRef]

43. Chung, S.-L.; Chu, M.-F.; Ji, J.; O'Reilly, S.Y.; Pearson, N.J.; Liu, D.; Lee, T.-Y.; Lo, C.-H. The nature and timing of crustal thickening in Southern Tibet: Geochemical and zircon Hf isotopic constraints from postcollisional adakites. Tectonophysics 2009, 477, 36-48. [CrossRef]

44. Aitchison, J.C.; Davis, A.M.; Badengzhu; Luo, H. New constraints on the India-Asia collision: The Lower Miocene Gangrinboche conglomerates, Yarlung Tsangpo suture zone, SE Tibet. J. Asian Earth Sci. 2002, 21, 251-263. [CrossRef]

45. Harrison, T.M.; Yin, A.; Grove, M.; Lovera, O.M.; Ryerson, F.J.; Zhou, X. The Zedong Window: A record of superposed Tertiary convergence in southeastern Tibet. J. Geophys. Res. Solid Earth 2000, 105, 19211-19230. [CrossRef]

46. Hou, Z.-Q.; Zheng, Y.-C.; Zeng, L.-S.; Gao, L.-E.; Huang, K.-X.; Li, W.; Li, Q.-Y.; Fu, Q.; Liang, W.; Sun, Q.-Z. Eocene-Oligocene granitoids in southern Tibet: Constraints on crustal anatexis and tectonic evolution of the Himalayan orogen. Earth Planet. Sci. Lett. 2012, 349, 38-52. [CrossRef]

47. Jiang, Z.Q.; Wang, Q.; Wyman, D.A.; Tang, G.J.; Jia, X.H.; Yang, Y.H.; Yu, X.X. Origin of 30 Ma Chongmuda adakitic intrusive rocks in the southern Gangdese region, southern Tibet: Partial melting of the northward subducted Indian continent crust? Geochimica 2011, 40, 126-146, (In Chinese with English abstract). 
48. Li, G.; Qin, K.; Ding, K.; Liu, T.; Li, J.; Wang, S.; Jiang, S.; Zhang, X. Geology, Ar-Ar Age and Mineral Assemblage of Eocene Skarn Cu-Au \pm Mo Deposits in the Southeastern Gangdese Arc, Southern Tibet: Implications for Deep Exploration. Resour. Geol. 2006, 56, 315-336. [CrossRef]

49. Zhang, L.-Y.; Ducea, M.N.; Ding, L.; Pullen, A.; Kapp, P.; Hoffman, D. Southern Tibetan Oligocene-Miocene adakites: A record of Indian slab tearing. Lithos 2014, 210-211, 209-223. [CrossRef]

50. Zheng, Y.-C.; Hou, Z.-Q.; Li, W.; Liang, W.; Huang, K.-X.; Li, Q.-Y.; Sun, Q.-Z.; Fu, Q.; Zhang, S. Petrogenesis and Geological Implications of the Oligocene Chongmuda-Mingze Adakite-Like Intrusions and Their Mafic Enclaves, Southern Tibet. J. Geol. 2012, 120, 647-669. [CrossRef]

51. Yamamoto, H.; Yamamoto, S.; Kaneko, Y.; Terabayashi, M.; Komiya, T.; Katayama, I.; Iizuka, T. Imbricate structure of the Luobusa Ophiolite and surrounding rock units, southern Tibet. J. Asian Earth Sci. 2007, 29, 296-304. [CrossRef]

52. Zhang, H.Y.; Ba, D.Z.; Guo, T.Y.; Mo, X.X.; Xue, J.Z.; Ruan, G.F.; Wang, Z.Y. Study of Luobusa Typical Chromite ore Deposit Qusong County, Tibet (Xizang); Xizang People Press: Xizang, China, 1996; p. 181, (In Chinese with English abstract).

53. Malpas, J.; Zhou, M.F.; Robinson, P.T.; Reynolds, P.H. Geochemical and geochronological constraints on the origin and emplacement of the Yarlung Zangbo ophiolites, Southern Tibet. Geol. Soc. Lond. Spec. Publ. 2003, 218, 191-206. [CrossRef]

54. Zhou, S.; Mo, X.X.; Mahoney, J.J.; Zhang, S.Q.; Guo, T.Y.; Zhao, Z.D. Geochronology and Nd and Pb isotope characteristics of gabbro dikes in the Luobusha ophiolite, Tibet. Chin. Sci. Bull. 2002, 47, 144-147.

55. Arai, S. Conversion of low-pressure chromitites to ultrahigh-pressure chromitites by deep recycling: A good inference. Earth Planet. Sci. Lett. 2013, 379, 81-87. [CrossRef]

56. Dobrzhinetskaya, L.F.; Wirth, R.; Yang, J.; Hutcheon, I.D.; Weber, P.K.; Green, H.W. High-pressure highly reduced nitrides and oxides from chromitite of a Tibetan ophiolite. Proc. Natl. Acad. Sci. USA 2009, 106, 19233-19238. [CrossRef] [PubMed]

57. Huang, M.X.; Yang, J.J.; Powell, R.; Mo, X.X. High-pressure metamorphism of serpentinized chromitite at Luobusha (southern Tibet). Am. J. Sci. 2014, 314, 400-433. [CrossRef]

58. Ji, W.-Q.; Wu, F.-Y.; Chung, S.-L.; Li, J.-X.; Liu, C.-Z. Zircon U-Pb geochronology and Hf isotopic constraints on petrogenesis of the Gangdese batholith, southern Tibet. Chem. Geol. 2009, 262, 229-245. [CrossRef]

59. Mo, X.; Hou, Z.; Niu, Y.; Dong, G.; Qu, X.; Zhao, Z.; Yang, Z. Mantle contributions to crustal thickening during continental collision: Evidence from Cenozoic igneous rocks in southern Tibet. Lithos 2007, 96, 225-242. [CrossRef]

60. Mo, X.; Niu, Y.; Dong, G.; Zhao, Z.; Hou, Z.; Zhou, S.; Ke, S. Contribution of syncollisional felsic magmatism to continental crust growth: A case study of the Paleogene Linzizong volcanic Succession in southern Tibet. Chem. Geol. 2008, 250, 49-67. [CrossRef]

61. Chung, S.-L.; Chu, M.-F.; Zhang, Y.; Xie, Y.; Lo, C.-H.; Lee, T.-Y.; Lan, C.-Y.; Li, X.; Zhang, Q.; Wang, Y. Tibetan tectonic evolution inferred from spatial and temporal variations in post-collisional magmatism. Earth-Sci. Rev. 2005, 68, 173-196. [CrossRef]

62. Lee, H.-Y.; Chung, S.-L.; Lo, C.-H.; Ji, J.; Lee, T.-Y.; Qian, Q.; Zhang, Q. Eocene Neotethyan slab breakoff in southern Tibet inferred from the Linzizong volcanic record. Tectonophysics 2009, 477, 20-35. [CrossRef]

63. Wen, D.-R.; Liu, D.; Chung, S.-L.; Chu, M.-F.; Ji, J.; Zhang, Q.; Song, B.; Lee, T.-Y.; Yeh, M.-W.; Lo, C.-H. Zircon SHRIMP U-Pb ages of the Gangdese Batholith and implications for Neotethyan subduction in southern Tibet. Chem. Geol. 2008, 252, 191-201. [CrossRef]

64. Zhu, D.-C.; Wang, Q.; Zhao, Z.-D.; Chung, S.-L.; Cawood, P.A.; Niu, Y.; Liu, S.-A.; Wu, F.-Y.; Mo, X.-X. Magmatic record of India-Asia collision. Sci. Rep. 2015, 5, 14289. [CrossRef] [PubMed]

65. Chung, S.; Liu, D.; Ji, J.; Chu, M.W.; Lee, H.; Wen, D.; Lo, C.; Lee, T.; Qian, Q.; Zhang, Q. Adakites from continental collision zones: Melting of thickened lower crust beneath southern Tibet. Geology 2003, 31, 1021-1024. [CrossRef]

66. Guo, Z.; Wilson, M.; Liu, J. Post-collisional adakites in south Tibet: Products of partial melting of subduction-modified lower crust. Lithos 2007, 96, 205-224. [CrossRef]

67. Miller, C.; Schuster, R.; Klötzli, U.; Frank, W.; Purtscheller, F. Post-Collisional Potassic and Ultrapotassic Magmatism in SW Tibet: Geochemical and $\mathrm{Sr}-\mathrm{Nd}-\mathrm{Pb}-\mathrm{O}$ Isotopic Constraints for Mantle Source Characteristics and Petrogenesis. J. Petrol. 1999, 40, 1399-1424. [CrossRef] 
68. Williams, H.; Turner, S.; Kelley, S.; Harris, N. Age and composition of dikes in Southern Tibet: New constraints on the timing of east-west extension and its relationship to postcollisional volcanism. Geology 2001, 29, 339-342. [CrossRef]

69. Kuiper, K.F.; Deino, A.; Hilgen, F.J.; Krijgsman, W.; Renne, P.R.; Wijbrans, J.R. Synchronizing Rock Clocks of Earth History. Science 2008, 320, 500-504. [CrossRef] [PubMed]

70. He, L.; Qiu, H.; Shi, H.; Zhu, J.; Bai, X.; Yun, J. A novel purification technique for noble gas isotope analyses of authigenic minerals. Sci. China: Earth Sci. 2016, 59, 111-117. [CrossRef]

71. Qiu, H.N.; Bai, X.J.; Liu, W.G.; Mei, L.F. Automatic ${ }^{40} \mathrm{Ar} /{ }^{39} \mathrm{Ar}$ dating technique using multicollector Argus VI MS with home-made apparatus. Geochimica 2015, 44, 477-484, (In Chinese with English abstract).

72. Koppers, A.A.P. ArArCALC—Software for ${ }^{40} \mathrm{Ar} /{ }^{39} \mathrm{Ar}$ age calculations. Comput. Geosci. 2002, 28, 605-619. [CrossRef]

73. Yang, L.; Wang, F.; Feng, H.; Wu, L.; Shi, W. ${ }^{40} \mathrm{Ar} /{ }^{39} \mathrm{Ar}$ geochronology of Holocene volcanic activity at Changbaishan Tianchi volcano, Northeast China. Quat. Geochronol. 2014, 21, 106-114. [CrossRef]

74. He, H.Y.; Wang, X.L.; Zhou, Z.H.; Jin, F.; Wang, F.; Yang, L.K.; Ding, X.; Boven, A.; Zhu, R.X. ${ }^{40} \mathrm{Ar} /{ }^{39} \mathrm{Ar}$ dating of Lujiatun Bed (Jehol Group) in Liaoning, northeastern China. Geophys. Res. Lett. 2006, 33, L04303. [CrossRef]

75. Ballentine, C.J.; Burnard, P.G. Production, release and transport of noble gases in the continental crust. Rev. Mineral. Geochem. 2002, 47, 481-538. [CrossRef]

76. Chen, L.; Qin, K.-Z.; Li, G.-M.; Li, J.-X.; Xiao, B.; Zhao, J.-X.; Fan, X. Zircon U-Pb ages, geochemistry, and $\mathrm{Sr}-\mathrm{Nd}-\mathrm{Pb}-\mathrm{Hf}$ isotopes of the Nuri intrusive rocks in the Gangdese area, southern Tibet: Constraints on timing, petrogenesis, and tectonic transformation. Lithos 2015, 212, 379-396. [CrossRef]

77. Gao, Y.; Hou, Z.; Kamber, B.S.; Wei, R.; Meng, X.; Zhao, R. Adakite-like porphyries from the southern Tibetan continental collision zones: Evidence for slab melt metasomatism. Contrib. Mineral. Petrol. 2007, 153, 105-120. [CrossRef]

78. Chen, L.; Qin, K.; Li, J.; Xiao, B.; Li, G.; Zhao, J.; Fan, X. Fluid Inclusions and Hydrogen, Oxygen, Sulfur Isotopes of Nuri Cu-W-Mo Deposit in the Southern Gangdese, Tibet. Resour. Geol. 2011, 62, 42-62. [CrossRef]

79. Caritat, P.D.; Hutcheon, I.; Walshe, J.L. Chlorite Geothermometry: A Review. Clays Clay Miner. 1993, 41, 219-239. [CrossRef]

80. Liang, F.H.; Xu, Z.Q.; Ba, D.Z.; Xu, X.Z.; Liu, F.; Xiong, F.H.; Jia, Y. Tectonic occurrence and emplacement mechanism of ophiolites from Luobusa-Zedang, Tibet. Acta Petrol. Sin. 2011, 27, 3255-3268, (In Chinese with English abstract).

81. Quidelleur, X.; Grove, M.; Lovera, O.M.; Harrison, T.M.; Yin, A.; Ryerson, F.J. Thermal evolution and slip history of the Renbu Zedong Thrust, southeastern Tibet. J. Geophys. Res. Solid Earth 1997, 102, 2659-2679. [CrossRef]

82. Yin, A.; Harrison, T.M.; Murphy, M.A.; Grove, M.; Nie, S.; Ryerson, F.J.; Xiao Feng, W.; Zeng Le, C. Tertiary deformation history of southeastern and southwestern Tibet during the Indo-Asian collision. Geol. Soc. Am. Bull. 1999, 111, 1644-1664. [CrossRef]

(C) 2018 by the authors. Licensee MDPI, Basel, Switzerland. This article is an open access article distributed under the terms and conditions of the Creative Commons Attribution (CC BY) license (http://creativecommons.org/licenses/by/4.0/). 